\title{
Early Diagnosis Of Chronic Kidney Disease
}

\author{
Itágores Hoffman II Coutinho* \\ Department of Nephrology, Federal University of Tocantins Palmas, Brazil
}

Submission: April 03, 2017; Published: May 24, 2017

*Corresponding author: Itágores Hoffman II Coutinho, Department of Nephrology, Federal University of Tocantins Palmas, Brazil, Tel: + 5563

3216-2659; E-mail: itagores2@uft.edu.br/itagores2@usp.br

Keywords: Chronic Kidney disease; Renal disease; Renal replacement therapy

\section{Introduction}

Chronic Kidney disease (CKD) is a global health problem. The exact number of people with CKD is world widely unknown. There is a rising incidence and prevalence of CKD in the United States. In 2014 alone, 120,688 thousand patients began their renal replacement therapy program in the country. The rising of prevalence of people with CKD in a renal replacement therapy program can be attributed, mainly, to the number of patients who begin their therapy every year, and secondly, to the rise of patients who survive terminal chronicle kidney diseases. According to the Brazilian Society of Nephrology, there is an increasing rise of renal replacement therapy programs in Brazil. This increase goes from 150pmp in 1994 to 596pmp in 2016 [1]. This year the number of patients under renal replacement therapy was 122.825 [1]. Unfortunately, renal disease, which has worldwide high prevalence, is under diagnosed and/or undertreated resulting in loss opportunities for prevention [24].

\section{Definition of CKD}

The work of the National Kidney Foundation -Kidney Disease Improving Global Outcomes (NKF-KDIGO) defined chronic renal disease in the following way, which has been world widely accepted:

o Presence of renal damage markers for over 3 months, defined structured or functional kidney abnormalities, with or without the decrease of the Glomerular filtration rate (GFR), which can lower the GRF, manifested by any pathological abnormalities or renal damage, including blood or urine composition alterations, or image exam alterations.

Or

o Presence of GFR $<60 \mathrm{ml} / \mathrm{min} / 1,73 \mathrm{~m} 2$ for over the period of 3 months, with or without other signs of renal damage listed previously.

\section{Screening Chronic Kidney Disease}

The guidelines given by NKF-KDIGO for CKD recommend that all individuals who look for health plans must be checked up in order to verify risks of developing renal disease [5-7].

In general, the presence of the following risk factors for CKD must encourage laboratorial tests for renal disease detection:

o Diabetes mellitus background, arterial hypertension, cardiovascular disease, dyslipidemia, obesity, metabolic syndrome, HIV or hepatitis C infection and neoplasms.

o Family history of CKD.

o Older than 60 years old.

o Use of nephrotoxic drugs.

Of the factors listed above, diabetes background and cardiovascular disease represent the highest risks of developing CKD [7].

Simple tests like urine or protein/creatinine relation analysis in a casual urine sample and serum creatinine levels are effective in screening for CKD8.Screening for hematuria should be performed in populations with increased risk for glomerulonephritis [7].

\section{SCORED - Screening for Occult Renal Disease}

SCORED is a new model of chronic kidney disease screening, recently used to identify individuals with high probability for prevalent CKD. This systematic method elaborated from data collected through NHANES 1999-2000 and 2001-2002. SCORED ponders common variables associated with chronic kidney diseases and can be useful to identify individuals with high probability for occult renal disease in general population [8]. Individuals who obtained a score of $\geq 4$ points classify as high risk for CKD and those with lower scores, as low risk of CKD. 
Table 1 summarizes the variables analyzed using Scored and their respective scores [9].

Table 1: Risk variables for CKD [9].

\begin{tabular}{|c|c|c|}
\hline Variables & Presence & Points \\
\hline Age between 50 and 59 & Yes & 2 \\
\hline Age between 60 and 70 & Yes & 3 \\
\hline Age over 70 & Yes & 4 \\
\hline Woman & Yes & 1 \\
\hline Anemic & Yes & 1 \\
\hline Arterial Hypertension & Yes & 1 \\
\hline Mellitus diabetes & Yes & 1 \\
\hline AMI/CVA & Yes & 1 \\
\hline CHF & Yes & 1 \\
\hline Peripheral arterial disease & Yes & 1 \\
\hline Proteinuria & Yes & 1 \\
\hline AMI/CVA: Acute myocardial infarction/ & & \\
\hline Stroke & & \\
\hline CHF: Congestive heart failure & & \\
\hline
\end{tabular}

\section{Conclusion}

SCORED can be useful in screening this disease in general population. Due to its easy applicability and low cost, it should be implemented among the health policies of basic attention and encourage doctors to use this tool as initial triage. After one could easily investigate CKD through serum dosage of creatinine, urine 1 sample with or without image exams.

\section{References}

1. Brazilian Society of Nephrology. Brazil.

2. McClellan WM, Knight DF, Karp H, Brown WW (1997) Early detection and treatment of renal disease in hospitalized diabetic and hypertensive patients: important differences between practice and published guidelines. Am J Kidney Dis 29(3): 368-375.

3. Nissenson AR, Collins AJ, Hurley J, Petersen H, Pereira BJ, et al. (2001) Opportunities for improving the care of patients with chronic renal insufficiency: current practice patterns. J Am SocNephrol 12(8): 17131720.

4. Obrador GT, Pereira BJ, Kausz AT (2002) Chronic kidney disease in the United States: an under recognized problem. SeminNephrol 53(4): 681-688.

5. United States Renal Data System (2016) Annual Data Report: Atlas of Chronic Kidney Disease and End-Stage Renal Disease in the United States. National Institutes of Health, National Institute of Diabetes and Digestive and Kidney Diseases, Bethesda, USA.

6. National Kidney Foundation (2012) KDIGO 2012 Clinical Practice Guideline for the Evaluation and Management of Chronic Kidney Disease. Kidney International Supplements 3: 5-14.

7. Levey AS, Atkins R, Coresh J, et al. (2007) Chronic kidney disease as a global public health problem: approaches and initiatives - a position statement from Kidney Disease Improving Global Outcomes. Kidney Int 72(3): 247-259.

8. Ruilope L, Antonio S, Jamerson K, Hansson L, Warnold I, et al. (2001) Renal function and intensive lowering of blood pressure in hypertensive participants of the hypertension optimal treatment (HOT) Study. J Am SocNephrol 12(2): 218-225.

9. Bang H, Vupputuri S, Shoham DA, Klemmer PJ, Falk RJ, et al. (2007) SCreening for Occult REnal Disease (SCORED): a simple prediction model for chronic kidney disease. Arch Intern Med 167(4): 374-381.

\section{Your next submission with Juniper Publishers will reach you the below assets}

- Quality Editorial service

- Swift Peer Review

- Reprints availability

- E-prints Service

- Manuscript Podcast for convenient understanding

- Global attainment for your research

- Manuscript accessibility in different formats

( Pdf, E-pub, Full Text, Audio)

- Unceasing customer service

Track the below URL for one-step submission https://juniperpublishers.com/online-submission.php 